\title{
Ingested foreign body associated with tooth extraction: Report of a case
}

\author{
Ingestão de corpo estranho associado à exodontia: Relato de caso \\ Ingestión de cuerpo extraño asociada a extracción dentaria: Reporte de caso
}

Received: 04/19/2021 | Reviewed: 04/30/2021 |Accept: 05/04/2021 |Published: 05/17/2021

\author{
Stéfani Caroline Ferriolli \\ ORCID: https://orcid.org/0000-0003-0019-6026 \\ Universidade Estadual Paulista, Brasil \\ E-mail: stefani.ferriolli@outlook.com \\ Luan Pier Benetti \\ ORCID: https://orcid.org/0000-0002-3592-8330 \\ Universidade Estadual Paulista, Brasil \\ E-mail: luanpierbenetti@gmail.com \\ Ana Maira Pereira Baggio \\ ORCID: https://orcid.org/0000-0002-9474-5091 \\ Universidade Estadual Paulista, Brasil \\ E-mail: anamairabaggio@gmail.com \\ Vinícius Ferreira Bizelli \\ ORCID: https:// orcid.org/0000-0003-1813-3509 \\ Universidade Estadual Paulista, Brasil \\ E-mail: viniciusbizelli@gemail.com \\ Edith Umasi Ramos \\ ORCID: https:// orcid.org/0000-0002-6077-7597 \\ Universidade Estadual Paulista, Brasil \\ E-mail: yassed_20@hotmail.com \\ Daniela Ponzoni \\ ORCID: https://orcid.org/0000-0001-5928-0914 \\ Universidade Estadual Paulista, Brasil \\ E-mail: Daniela.ponzoni@unesp.br \\ Ana Paula Farnezi Bassi \\ ORCID: https://orcid.org/0000-0002-0031-4953 \\ Universidade Estadual Paulista, Brasil \\ E-mail: ana.bassi@unesp.br
}

\begin{abstract}
Aspiration and ingestion of teeth, dental prostheses and other foreign bodies in maxillofacial injuries is a known complication necessitating prompt recognition and early treatment to minimize potentially serious and, sometimes, even fatal consequences. However, an aspirated or ingested foreign body does not always produce untoward affects and may be overlooked when no acute respiratory distress is evident or multiple life-threatening injuries are present. Here, we report a case in its presentation; the patient underwent extraction of a left upper third molar. After extraction, alveolar irrigation was performed with syringe, needle and sterile saline. the patient ingested the irrigation needle. The patient was properly referred to the emergency room of the hospital of Santa Fé do Sul and referred to the care of the general surgeon, who removed the needle with endoscopic removal under sedation. Clinicians must be aware that the instrument used for dental treatment are mostly small and there is a risk of these falling into the oropharynx and being swallowed or inhaled. The paper also emphasizes that attention to the potentially serious consequences and to offer guidance on management.
\end{abstract}

Keywords: Respiratory aspiration; Foreign bodies; Endoscopic ultrasound-guided fine needle aspiration; Surgery, oral.

\section{Resumo}

Aspiração e ingestão de dentes, próteses dentárias e outros corpos estranhos em lesões maxilofaciais é uma complicação conhecida que necessita reconhecimento imediato e tratamento precoce para minimizar consequências potencialmente graves e, às vezes, até fatais. No entanto, um corpo estranho aspirado ou ingerido nem sempre produz efeitos indesejáveis e pode ser negligenciado quando nenhum desconforto respiratório agudo é evidente ou quando há presença de múltiplas lesões com risco de vida. Aqui, relatamos um caso em sua apresentação; o paciente foi submetido à exodontia de um terceiro molar superior esquerdo. Após a extração, a irrigação alveolar foi realizada com solução salina estéril, utilizando-se uma seringa de irrigação e uma agulha de metal que foi liberada da seringa e o paciente a ingeriu. Este foi encaminhado para a emergência do hospital do município de Santa Fé do Sul aos cuidados do cirurgião geral, que retirou a agulha com endoscópica sob sedação. Os médicos devem estar cientes de que os instrumentos usados para o tratamento odontológico são, na maioria das vezes, pequenos e há o risco de cair na 
orofaringe e serem engolidos ou inalados. $\mathrm{O}$ documento também enfatiza a atenção às consequências potencialmente graves e oferece orientação sobre a gestão.

Palavras-chave: Aspiração respiratória; Corpos estranhos; Aspiração por agulha fina guiada por ultrassom endoscópico; Cirurgia bucal.

\begin{abstract}
Resumen
La aspiración e ingestión de dientes, prótesis dentales y otros cuerpos extraños en lesiones maxilofaciales es una complicación conocida que requiere un reconocimiento inmediato y un tratamiento temprano para minimizar las consecuencias potencialmente graves y, a veces, incluso fatales. Sin embargo, un cuerpo extraño aspirado o ingerido no siempre produce efectos indeseables y puede ignorarse cuando no es evidente una dificultad respiratoria aguda o cuando hay múltiples lesiones potencialmente mortales. Aquí, reportamos un caso en su presentación; el paciente fue sometido a la extracción de un tercer molar superior izquierdo. Tras la extracción, se realizó irrigación alveolar con suero fisiológico estéril, utilizando una jeringa de irrigación y una aguja metálica que se desprendió de la jeringa y la paciente la ingirió. Este fue remitido a la sala de emergencias del hospital del municipio de Santa Fé do Sul bajo el cuidado del cirujano general, quien removió la aguja con un endoscopio bajo sedación. Los médicos deben ser conscientes de que los instrumentos utilizados para el tratamiento dental son, en la mayoría de los casos, pequeños y existe el riesgo de caer en la orofaringe y ser ingeridos o inhalados. El documento también enfatiza la atención a las consecuencias potencialmente graves y brinda orientación sobre la gestión.

Palabras clave: Aspiración respiratoria; Cuerpos extraños; Biopsia por aspiración con aguja fina guiada por ultrasonido endoscópico; Cirugía bucal.
\end{abstract}

\title{
1. Introduction
}

Foreign body aspiration (FBA) into the tracheobronchial tree is a frequent and serious cause of respiratory distress and visits to the hospital emergency (Senocak et al., 2003; Monini et al.,2011). Sudden onset of cyanosis, cough and wheezing are the principal symptoms described for this condition (Senocak et al., 2003). However, in other situations, there is scarcity of clinical signs, either due to spontaneous improvement of the patients or due to failure of diagnostic, on the part of clinical members, to report episodes of suffocation or choking. Foreign bodies vary in size and shape and range from endodontic instruments, burs, posts, root copings, teeth, orthodontic brackets, and impression materials to temporaries, implant components, and restorations (Pingarrón et al., 2010). Sometimes, it is possible to minimize the danger of inhalation or ingestion of root canal instruments using a rubber dam on a routine basis (Tiwana et al., 2004). However, there are situations in which the use of a rubber dam may not be feasible, such as treatment with dental implants. For implant treatment, the main precaution is to tether any screwdriver that has a small hole in its handle for this purpose; however, such tethering is not possible with other components (Monini et al., 2011; Tiwana et al., 2004). Some objects are made of materials that lack radiopacity, which makes it impossible to identify their position. Thus for an accurate diagnosis can be used to threedimensional CT reconstruction, rotine CT and chest x-ray examination (Pingarrón et al.,2010). Serious respiratory sequelae, such as recurrent pulmonary infections, bronchiectasis and destruction of the previously healthy lung parenchyma, can result from FBA (Burke et al.,2000) Correct interpretation and integration of history, physical examination and radiographic evidence are necessary to achieve an early diagnosis of foreign-body aspiration (Ludemann et al.,2000).

\section{Methodology}

This study is a case report in a qualitative and descriptive way, bringing relevant data from the literature regarding the Ingestion of foreign body associated with tooth extraction, its risks and the dentist's conduct. (Mohan et al., 2011), correlated to the presented clinical case of a 35-year-old female patient who underwent fibroscopy by mouth, after ingestion of an irrigation needle, during extraction of a third molar (Chelvarajah et al., 2004; Cohen et al.,2006). The study was approved by the Research Ethics Committee and the informed consent form was signed by the patient, following all protocols under the same consent form, respecting ethical principles. (Pereira et al., 2018; Estrela et al., 2018). 


\section{Clinical Report}

A female patient, JAB, 35 years old, leucoderma was treated at the surgery clinic of the Faculty of Dentistry of Santa Fé do Sul (FUNEC), State of São Paulo - Brazil, for extraction of the left upper third molar. An extra-buccal antisepsis was performed with $10 \%$ topical PVPI and intrabuccal with $0.12 \%$ chlorhexidine digluconate, surgical field apposition, infiltrative terminal anesthesia with 2\% mepivacaine hydrochloride anesthetic solution with epinephrine 1: 200,000. Then the syndesmotomy and the extraction of the dental element were done. The alveolar irrigation with physiological saline after the exodontia was performed with the help of glass Luer-Luc syringe with metallic needle, both sterile. At the moment of irrigation of the alveolus the needle detached from the syringe falling into the patient's oral cavity, which suddenly had the swallowing reflex. Since it was not possible to visually identify whether the patient had swallowed or aspirated the needle, it was immediately taken to the hospital nearest to the emergency department. During the initial clinical care it was observed that the patient was in good general condition, eupnea, acyanotic, contacting and normotensive. A chest X-ray was performed, which evidenced the presence of a metallic irrigation needle in the patient's stomach (Figure 1). Therefore, it was evaluated by the general surgery team and sent to the surgical center for upper digestive endoscopy (Cohen et al.,2006; Yin et al.,2015).

Figure 1. Posteroanterior chest radiograph showing implant screwdriver located in right main bronchus.

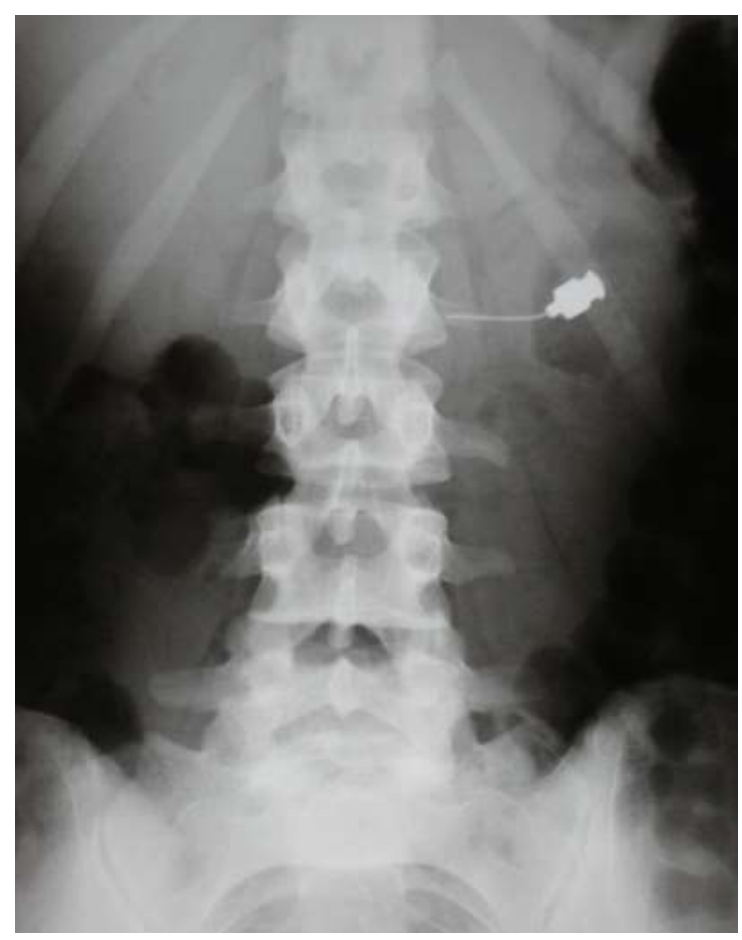

Source: Authors.

Aspirated foreign bodies are associated with a high incidence of morbidity and mortality. However, the outcome of these cases is very likely to be successful, using the correct technique for their removal (Robert et al.,2004). The radiographs serve as a guide, guiding the professional on the location of this foreign body and with that he is able to analyze what is the best conduct for the removal of this foreign body. As we see in the image (Figure A) the needle located in the patient's stomach, evaluated by the general surgery team that referred the patient to the operating room for upper gastrointestinal endoscopy. 
Figure 2. Irrigation needle removed.

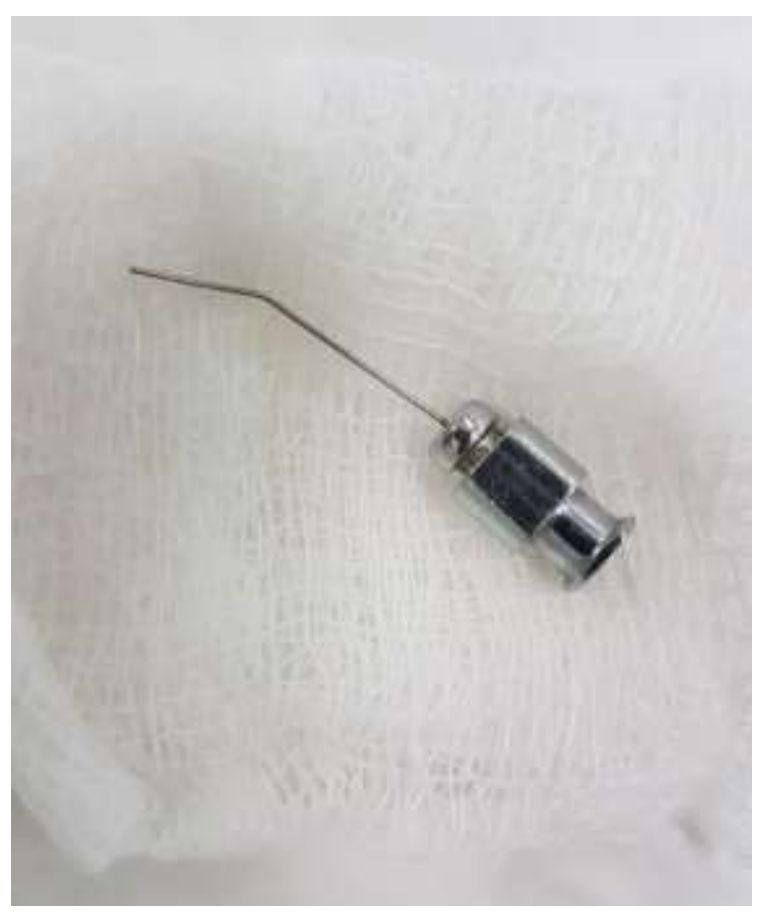

Source: Authors.

After intravenous sedation, in which $2 \mathrm{mg}$ of midazolam (Dormonid) was administered, the fibroscope was introduced orally through the oropharynx and esophagus until it reached the inside of the stomach. From that moment the foreign body was located and pinched being withdrawn retrograde, delicately in order to avoid perforations or lacerations of the disgestive tube (Figura 2).

After the procedure, the patient was slightly sleepy, but conscious and contacting, with stable vital signs, without sequelae or damages related to the accident and the procedure performed. She was discharged on the same day.

\section{Discussion}

The aspiration or ingestion of foreign bodies is recognized as a consequence of maxillofacial injuries and a complication during the provision of dental treatment. The outcome ranges from minimal symptoms, often unobserved, to respiratory compromise, failure and even death (Umesan et al., 2012). Adverse outcomes resulting from aspiration or ingestion of instruments and material can occur in any dental procedure. The incidence of these accidents increases when preventive methods are not used, such as: the use of absolute isolation in endodontic procedures and dental restorations procedures, the use of a wire tied in small instruments and the use of gauze in the oropharynx when the patient is sedated. The size, flexibility and shape of the object can have an influence on the compromise of the accident. (Fields et al., 1998). If aspiration or swallowing of a foreign body is suspected, chest and abdomen exams are essential for the diagnosis. When the foreign body is radiopaque, the location of the object is more accurate. Routine Computed Tomography (CT) is a highly sensitive diagnostic technique for detecting foreign bodies. This technique may demonstrate differences in lung parenchyma density and, like Chest XR, can also be used to visualize the object's radiolucency, such as plastic, toys, and other objects in the airways (Xiao et al., 2009).

Three-dimensional CT is another method for diagnosing aspiration or swallowing of the foreign body. A noninvasive technique provides an insight into the main trachea and bronchi in three dimensions of reconstruction. The three-dimensional 
CT reconstruction technique includes the merits of routine lung CT and X-ray examinations for the detection of foreign body aspiration (Hong et al., 2008; Huang et al., 2008). However, chest RX is the most appropriate method of diagnosis because it can be performed quickly, detect the shape, positioning of the object and is inexpensive (Xiao et al.,2009) In the clinical case described, Chest XR was used, which was sufficient to determine the location, size and radiolucency of the object. Some patients may spontaneously expel foreign bodies and non-surgical removal by positioning the patient with blows to the back has been described with good results (Xiao et al.. 2009). When a foreign body drops into the oropharynx, first of all, the patient should be positioned in reverse Trendelenburg position (in which the upper part of the body is raised $0^{\circ}$ to $30^{\circ}$ ) and asked to cough trying to regurgitate the inhaled object (Pingarrón et al.,2010). In case of foreign body aspiration, in with the patient may have breathing difficulties, it is recommended to perform the Heimlich maneuver in order to unblock the affected pathway. In this, a pressure is exerted on the diaphragm causing an act of forced cough that induces expulsion of the body (Tripathi et al.,2011). The management of airways in case of suspicion of aspiration and swallowing of foreign objects is very well elucidated by Martin, LP 2010.2 In the described clinical case there was ingestion of an instrument. The patient was referred to the hospital without airway compromise and the same procedures described by Martin, LP 2010.3. Depending on the positioning of the digestive tract, the patient should be made aware of the situation and advise on the examination of stools. Purgatives should be avoided because they increase the effect of a peristaltic contraction and can lead to intestinal perforation. Some authors (Campos (Fields et al., 1998; De Souza et al.,2012; Ludemann et al., 2000). cite the use of a mass-rich diet, but there is no scientific evidence on the benefit of any special diet for the passage of such objects. The risk of a foreign body causing perforation or obstruction is related to the shape and size of the object. Pointy objects are associated with a higher risk of drilling. Objects more than 5 centimeters are unlikely to pass from the duodenum. In both cases, early endoscopic removal needs to be fulfilled. Generally foreign bodies that cause obstruction in the digestive tract occur in the upper third of the esophagus (Henderson et al., 1987; Mohan et al., 2011). As a consequence, perforation of the esophagus with evolution to mediastinum and obstruction of the esophagus with risk of aspiration may occur (Tripathi et al., 2011). Therefore, the removal must be performed urgently through optic fiber by endoscopy (Pingarrón et al., 2010). Once the foreign body has reached the stomach, $90 \%$ of the objects pass directly into the gastrointestinal tract. This period can range from 7 to 10 days (Webb et al., 1988). Once an object has left the stomach, in most cases, it should pass through the small intestine. The most commonly affected site of perforation or obstruction is the ileocecal valve. A secondary diagnostic examination is colonoscopy. This evaluates the large intestine and ileum. The withdrawal of the object can be done by surgical intervention with exploratory laparostomy to highlight the location of the injury. In many cases when the object reaches the small intestine it is expelled in the stool, so there is not needing surgery. The complications of intestinal obstruction may be perforation with formation of abscess, hemorrhage, and fistulas (Pingarrón et al., 2010).

\section{Final Considerations.}

Irrigation is a process of fundamental importance during extraction. However, the dentist must have knowledge and mastery of the technique and instruments used, to know how to act during the surgery, avoiding possible complications as these episodes can cause in life-threatening medical emergencies. Therefore, prevention through the mandatory use of all care during dental procedures is the best approach to avoid serious consequences. In the case of swallowing an object, it is essential ensure the person's airway, followed by the locating later if the object is in the digestive or respiratory tract to establish the appropriate treatment. 


\section{References}

Bergermann, M., Donald, P. J., \& Wengen, D. F. Screwdriver aspiration. A complication of dental implant placement. Int J Oral Maxillofac Surg 1992; $21: 339-341$.

Burke, A. J., Vining, D. J., McGuirt, W. F. Jr. et al. Evaluation of airway obstruction using virtual endoscopy. Laryngoscope 2000; 110(1):23-9.

Chelvarajah R, Bycroft J. Writing and publishing case reports: the road to success. Acta Neurochir, 146: 313-6, 2004.

Cohen H. How to write a patient case report. Am J Health Syst Pharm, 63: 1888-92.

De Souza, J. G., Schuldt Filho, G., Pereira Neto, A. R., et al. Accident in implant dentistry: involuntary screwdriver ingestion during surgical procedure. A clinical report. J Prosthodont. 2:191-193.

Estrela, C. (2018). Metodologia Científica: Ciência, Ensino, Pesquisa. Editora Artes Médicas.

Fields, R. T., \& Schows, S. R. Aspiration and ingestion of foreignbodies in oral and maxillofacial surgery; a review of the literature and report of five cases. Am J Oral Maxillofacial Surg; 5 6:1091- 1098.

Henderson, C. T., Engel, J., \& Schlesinger, P. Foreign body ingestion; review and suggested guidelines for management. Endoscopy 19:68-71.

Hong, S. J., Goo, H. W., \& Roh, J. L. Utility of spiral and cine CT scans in pediatric patients suspected of aspirating radiolucent foreign bodies. Otolaryngol Head Neck Surg 2008; 138:576Y580.

Huang, H. J., Fang, H. Y., Chen, H. C., et al. Three-dimensional computed tomography for detection of tracheobronchial foreign body aspiration in children. Pediatr Surg Int 2008; 24:157Y160.

Ludemann, J. P., Hughes, C. A., Holinger, L. D. Management of foreign bodies of the airway: In: Shields, T. W., LoCicero, J., Ponn, R. B., editors. General thoracic surgery. 5th ed. Philadelphia: Lippencott Williams \& Wilkens; 853-61.

Robert Sean Miller, J Paul Willging, Michael J Rutter, Korpong Rookkapan. Chronic esophageal foreign bodies in pediatric patients: a retrospective review. Int J Pediatr Otorhinolaryngol. 68(3):265-72.

Monini, A. C., Maia, L. G., Jacob, H. B., \& Gandini, L. G. Accidental swallowing of orthodontic expansion appliance key. Am J Orthod Dentofacial Orthop. 140:266-268.

Mohan, R., Rao, S., Benjamin, M., \& Bhagavan, R. K. Accidental ingestion of a barbed wire broach and its endoscopic retrieval: prevention better than cure. Indian J Dent Res. 22:839-842.

Pereira, A. S., Shitsuka, D. M., Parreira, F. J., \& Shitsuka, R. (2018). Metodologia da Pesquisa Científica. UFSM.

Pingarrón Martín, L., Morán Soto, M. J., Sanchez Burgos, R., et al. Bronchial impaction of an implant screwdriver after accidental aspiration: report of a case and revision of the literature. Oral Maxillofac Surg 14(1):43-7.

Senocak, M. E., et al. CT virtual bronchoscopy in the evaluation of children with suspected foreign body aspiration. Eur J Radiol 2003 ; 48(2):188-92.

Souza, F. A., Statkievicz, C., Guilhem Rosa, A. L., \& Da Silveira Bossi, F., Management of accidental swallowing in implant dentistry. Journal of Prosthetic Dentistry, 114(2), 2015; $167-170$.

Tiwana, K. K., Morton, T., \& Tiwana, P. S. Aspiration and ingestion in dental practice: a 10-year institutional review. J Am Dent Assoc 2004; $135: 1287-1291$.

Tripathi, T., Rai, P., \& Sing, H. Foreign body ingestion of orthodontic origin. Am J Orthod Dentofacial Orthop 2011; 139:279-83).

Umesan, U. K., Chua, K. L., \& Balakrishnan, P. Prevention and management of accidental foreign body ingestion and aspiration in orthodontic practice. Ther Clin Risk Manag. 8: 245-252.

Webb, W. A. Management of foreign bodies of the upper gastrointestinal tract. Gastroenterol 1988; 94:204-216.

Xiao, W. L., Zhang, D. Z., \& Wang, Y. H. Aspiration of two permanent teeth during maxillofacial injuries. J Craniofac Surgery 2009;20(2):558-60.

Yin, R. K. (2015). O estudo de caso. Bookman. 